\title{
Systematic evaluation of factors controlling Perkinsus marinus transmission dynamics in lower Chesapeake Bay
}

\author{
Lisa M. Ragone Calvo ${ }^{1, *}$, Christopher F. Dungan², Bob S. Roberson ${ }^{3}$, \\ Eugene M. Burreson ${ }^{1}$
}

\footnotetext{
${ }^{1}$ Virginia Institute of Marine Science, College of William and Mary, Gloucester Point, Virginia 23062, USA

${ }^{2}$ Maryland Department of Natural Resources, Cooperative Oxford Laboratory, Oxford, Maryland 21654, USA

${ }^{3}$ Department of Microbiology, University of Maryland, College Park, Maryland 20742, USA
}

\begin{abstract}
The transmission of Perkinsus marinus in eastern oysters Crassostrea virginica in relation to water temperature, host oyster mortality, and water-column abundance of anti- $P$. marinus antibody-labeled cells was systematically examined for 20 mo at a site in the lower York River, Virginia, USA. Uninfected sentinel oysters were naturally exposed to the parasite at 2 wk intervals throughout the course of the study to determine the periodicity and rates of parasite transmission. The timing and magnitude of disease-associated oyster mortalities in a local P. marinus-infected oyster population were estimated by monitoring a captive subset of the local oyster population. Flow cytometric immunodetection methods were employed to estimate the abundance of $P$. marinus cells in water samples collected 3 times each week. The acquisition of $P$. marinus infections by naïve sentinel oysters occurred sporadically at all times of the year; however, the highest incidence of infection occurred during the months of August and September. This window of maximum parasite transmission coincided with the death of infected hosts within the captive local oyster population. Counts of antibody-labeled cells ranged from 10 to 11900 cells $^{-1}$, with the highest abundances in July and August coincident with maximum summer temperatures. A statistically significant relationship between water-column parasite abundance and infection-acquisition rate was not observed; however, highest parasite-transmission rates in both years occurred during periods of elevated watercolumn abundance of parasite cells. These results support the prevailing model of $P$. marinus transmission dynamics by which maximum transmission rates are observed during periods of maximum P. marinus-associated host mortality. However, our results also indicate that transmission can occur when host mortality is low or absent, so alternative mortality-independent dissemination mechanisms are likely. The results also suggest that atypically early-summer oyster mortality from Haplosporidium nelsoni infection, at a time when infections of $P$. marinus are light, has a significant indirect influence on $P$. marinus transmission dynamics. Elimination of these hosts prior to late-summer P. marinus infection-intensification effectively reduces the overall number of $P$. marinus cells disseminated.
\end{abstract}

KEY WORDS: Perkinsus marinus $\cdot$ Crassostrea virginica $\cdot$ Disease $\cdot$ Parasite $\cdot$ Antibody-labeled cells · Flow cytometry $\cdot$ Abundance $\cdot$ Transmission dynamics

\section{INTRODUCTION}

Perkinsus marinus is a protistan parasite of the eastern oyster Crassostrea virginica that has been responsible for severe oyster mortalities in the mid-Atlantic region of the USA. Historically, this parasite was absent from a large proportion of the oyster grounds located in the upper reaches of Chesapeake Bay tributaries, but in the last decade, as a consequence of several drought years, its distribution has expanded 
and it is now present on nearly all oyster bars in Chesapeake Bay (Burreson \& Ragone Calvo 1996, Ragone Calvo \& Burreson 1999). P. marinus exhibits a distinct seasonal cycle, with minimum prevalence and intensity in early spring, and maximum prevalence and intensity in late summer. Annual prevalence maxima in adult oysters inhabiting moderate- to high-salinity areas in Chesapeake Bay are typically 100\%, and infection intensities are frequently lethal.

The prevailing conceptual model of Perkinsus marinus transmission for Chesapeake Bay asserts that transmission occurs via the direct dissemination of waterborne infective cells released upon the death and decomposition of infected oysters (Andrews 1988, Burreson \& Ragone Calvo 1996). The abundance of disseminated cells is believed to be highest in August and September, during periods of epizootic oyster mortalities. The rate of infection in nature is believed to be proportional to the abundance of water-borne infective pathogen cells, and to be increased by close proximity to infected hosts (Andrews \& Hewatt 1957). Evidence of direct transmission includes the establishment of infections in oysters exposed to crude minces of infected oyster tissues and to isolated cells of various life stages (Ray 1954, Mackin 1962, Volety \& Chu 1994). Such investigations have also shown that transmission is dosedependent and that all known life stages of $P$. marinus are infective (Perkins 1988, Volety \& Chu 1994).

Investigations of disease transmission in nature have been limited to estimations of seasonal infection pressure in sentinel populations of uninfected oysters transplanted annually to endemic areas. Andrews \& Hewatt (1957) found that uninfected oysters imported into endemic Chesapeake Bay waters in spring developed detectable infections in late summer, a time corresponding to epizootic deaths of oysters harboring Perkinsus marinus infections. Similarly, annual imports of sentinel oyster populations have been utilized to discern annual variability of $P$. marinus infection pressure (Ragone Calvo \& Burreson 1999). These studies have relied on temporal disease prevalence and intensity data to make inferences concerning the timing and magnitude of transmission events. Although useful, such epidemiological studies have been limited by the low sensitivity of standard diagnostic techniques for detecting early infection (Bushek et al. 1994).

Development of a flow cytometric method for the quantification of Perkinsus marinus cells in environmental water samples has provided the first opportunity to directly monitor environmental abundances of putative $P$. marinus cells and to estimate seasonal abundances of water-borne $P$. marinus cells. The flow cytometric method utilizes antibodies to selectively fluorochrome-label P. marinus cells (Dungan \& Roberson 1993). Immuno-labeled $P$. marinus cells in water samples are then counted with a flow cytometer. This technique has been used to monitor environmental abundances of the parasite in the Tred Avon River, Maryland, over a 2 yr period (Roberson et al. 1993, Ashton-Alcox et al. 2000).

In the present study we examined the relationship among Perkinsus marinus abundance in the water column as determined by flow cytometry, local oyster mortality, and $P$. marinus infection-acquisition rate in uninfected sentinel oysters. This study is the first empirical test of long-standing hypotheses on mechanisms and dynamics of $P$. marinus transmission.

\section{MATERIALS AND METHODS}

Water sample collection. Water samples were collected 3 times each week from April 1994 through December 1995. The sampling site was at the Virginia Institute of Marine Science (VIMS) pier in the York River (YR) at Gloucester Point, Virginia. This moderate-salinity (18 to $24 \mathrm{ppt}$ ) area is enzootic for Perkinsus marinus. The area is no longer heavily populated by oysters, but small aggregate populations of local oysters exist.

Water samples (1.0 l) were collected from a depth of $1 \mathrm{~m}$ at approximately the same time each day to randomize tidal effects. Temperature and salinity were determined immediately after collection with a thermometer and a hand-held refractometer, respectively. Water samples were returned to the laboratory and immediately filtered through a $35 \mu \mathrm{m}$ pore-size nylon sieve to remove large particles. Filtered samples were dispensed evenly into four $250 \mathrm{ml}$ conical centrifuge bottles. Formaldehyde (37\%) was added to each bottle to a final concentration of $1.0 \%(\mathrm{w} / \mathrm{v})$ and the samples were fixed for $1 \mathrm{~h}$ at room temperature. After fixation, particles were pelleted by centrifugation at $1500 \quad g$ for $15 \mathrm{~min}$, and supernatants were removed by aspiration. Pellets from all 4 bottles were pooled and resuspended in $10 \mathrm{ml}$ of $0.15 \mathrm{M}$ phosphate-buffered saline (PBS, $\mathrm{pH}$ 7.4) containing $0.04 \%(\mathrm{w} / \mathrm{v})$ sodium azide as preservative. Samples were stored at $4^{\circ} \mathrm{C}$ until analyzed by flow cytometry.

Flow cytometric enumeration of Perkinsus marinus cells. Antibody-labeled sample cells were analyzed with a Coulter EPICS 751 flow cytometer, using an argon laser tuned to $488 \mathrm{~nm}$ (blue light) as the illumination source, and either a $76 \mu \mathrm{m}$ flow cell or a $76 \mu \mathrm{m}$ Sense-in-Quartz ${ }^{\mathrm{TM}}$ sorting cell. Sample cells were analyzed for size by forward-angle light scatter (FALS), for surface texture and internal structure; by $90^{\circ}$ light scatter (90LS), for antibody labeling by green fluorescein fluorescence (FITCL, $525 \pm 10 \mathrm{~nm}$ ); and for red chlorophyll autofluorescence (REDFL, $635 \pm 10 \mathrm{~nm}$ ). 
We developed 4 parameter flow cytometric enumeration gates for Perkinsus sp. cells empirically by sorting different subpopulations of immuno-stained cells that were differentiated, alone or in combination, by their FITCL, REDFL, FALS and 90LS signal characteristics. Experimental cell subpopulations were sorted onto $1.0 \mu \mathrm{m}$ pore size, black polycarbonate membranes for microscopic evaluation of homogeneous morphological characteristics consistent with those described for histozoic, cultured, or dispersed P. marinus cells (Dungan \& Roberson 1993, Perkins 1996, Sunila et al. 2001).

Experimental cell suspensions that were sequentially used to establish Perkinsus sp. enumeration gate tolerances included (1) axenic in vitro-propagated P. marinus isolate cells ATCC 50439 (Dungan \& Hamilton 1995), (2) suspended cells from an experimental aquarium in which $P$. marinus-infected oyster tissues had been allowed to decompose for $10 \mathrm{~d}$, and (3) pooled particulate fractions collected thrice weekly during 1 yr, from $P$. marinus disease-endemic estuarine waters in a Chesapeake Bay oyster sanctuary (Roberson et al. 1995). Gated ranges for each parameter were narrowed until cells sorted from environmental samples were homogeneous and morphologically consistent with described $P$. marinus characteristics including diameters of 2 to $20 \mu \mathrm{m}$ (low FALS), smooth spherical surfaces (low 90LS), strong antibody binding (high FITCL), and the absence of autofluorescent photosynthetic pigments (baseline REDFL).

Perkinsus marinus cells in water samples were sorted into 2 subpopulations, mono-dispersed cells, and 2- to 4-cell aggregates, by non-overlapping gates (see Dungan \& Roberson 1993). Parasite cell abundances were estimated by combining counts from both enumeration gates and volumetrically normalizing for the proportion of the water sample analyzed. Enumeration efficiency was not systematically estimated during this study. However, independent microscopic enumeration of immunostained $P$. marinus cells in several samples consistently yielded higher counts than flow cytometric enumeration. Thus, the flow cytometric counting gates developed to sort $P$. marinus cell populations from heterogeneous plankton samples did not appear to enumerate non-Perkinsus sp. cells, but may have underestimated actual environmental parasite cell abundances (T. Li pers. comm.).

Prior to analysis with the flow cytometer, 0.25 to $1.0 \mathrm{ml}$ of fixed cell suspensions were washed 3 times at $1250 g$ in $10 \mathrm{ml}$ PBS. Washed cells were pelleted at $1250 \mathrm{~g}$, blocked by incubation for $1 \mathrm{~h}$ in $1.0 \%$ (v/v) normal goat serum, and washed with PBS containing $0.05 \%$ Tween 20 (PBST) before repelleting at $1250 \mathrm{~g}$. Blocked subsample pellets were incubated for 1 to $2 \mathrm{~h}$ in $1.0 \mathrm{ml}$ of a polyclonal rabbit antiserum against in vitro-propagated Perkinsus marinus (Isolate ATCC
50439) whole cells (Dungan \& Hamilton 1995) diluted in PBS to $3.310^{-3}\left(\sim 1 \mu \mathrm{g} \mathrm{ml} \mathrm{m}^{-1}\right)$. Except that the immunogen cell type differed, this antiserum was prepared by the same methods used by Dungan \& Roberson (1993), and had a specificity identical to that of the anti- $P$. marinus antibodies described by Bushek et al. (2002a). Following primary antibody labeling, cells were washed 3 times by centrifugation in PBS. Cell pellets were incubated for $1 \mathrm{~h}$ in $0.5 \mu \mathrm{g} \mathrm{ml} \mathrm{m}^{-1}$ FITClabeled goat $\mathrm{F}\left(\mathrm{AB}^{\prime}\right)_{2}$ fragments of anti-rabbit IgG (Sigma) made in PBS. Labeled cells were washed 3 times by centrifugation and finally resuspended in $0.4 \mathrm{ml}$ PBS. Subsamples representing 2.5 to $10 \%$ of the original 11 sample were resuspended and used for FITC-discriminated counts at the rate of 200 to 400 counts $\mathrm{s}^{-1}$ (cps).

Optical alignment of the flow cytometer was performed daily using optical alignment fluorospheres (DNA-Check ${ }^{\mathrm{TM}}$, Coulter). FALS was calibrated to particle diameter using latex beads, of 2, 6 and $10 \mu \mathrm{m}$ diameters. We generated 2-parameter and 4-parameter counting and sorting maps using modal FITCL, REDFL, FALS and 90LS signal ranges generated by a pure standard of cultured Perkinsus marinus cells (Dungan \& Hamilton 1995). Signal ranges for each parameter were recorded in list mode, using a 3decade logarithmic scale mapped onto 256 channels, and downloaded to an EPICS Easy $88^{\mathrm{TM}}$ computer system for storage and analysis. For each water sample, cell suspensions were mechanically agitated prior to analysis and analyzed until exhausted.

Estimation of local host-oyster mortality. Because there are no concentrations of oysters remaining in the study area, Perkinsus marinus-infected adult oysters ( $\mathrm{n}=1000)$ were collected in late March 1994 and 1995 from Point of Shoals, a P. marinus enzootic area located in the upper James River, Virginia. Following collection, the oysters were transferred to our study site in the lower York River at Gloucester Point, where they were suspended from a pier near-bottom in 4 replicate retrievable trays $(\mathrm{n}=250$ per tray). $P$. marinus prevalence at the Point of Shoal site in the preceding fall collection was $100 \%$. It is typical for prevalence at this location to decline during the late fall and winter to $0 \%$ or near $0 \%$; however, it has been demonstrated that subclinical infections remain at $>70 \%$ prevalence (Ragone Calvo \& Burreson 1993). These overwintering infections typically intensify and become clinical in early summer. Following deployment, the transplanted James River oysters were retrieved biweekly, and dead and live oysters were enumerated. Hereafter these oysters will be referred to as infected native oysters.

Mortality was calculated as follows. Interval mortality (mortality occurring between enumeration dates) 
was determined for each replicate group by dividing the number of oysters that died during the interval by the number of oysters that were alive at the beginning of the interval. Interval mortality was then multiplied by the proportion of survivors of the previous interval (1-cumulative mortality of preceding interval) to yield an adjusted interval mortality. Successive cumulative mortalities were determined by summing adjusted interval mortalities and preceding cumulative mortalities. Mortality rate $\left(\%\right.$ mortality $\left.\mathrm{d}^{-1}\right)$ was calculated by dividing adjusted interval mortality by the number of days in the interval.

Dead oysters still containing tissue were analyzed for both Perkinsus marinus and Haplosporidium nelsoni, if enough tissue remained. Ray's fluid thioglycollate medium (RFTM) assays were used to diagnose P. marinus infections (Ray 1954), and paraffin histology was used to diagnose $H$. nelsoni infections. P. marinus infection intensities were rated according to Ray (1954); however, for presentation of results, the 6 infection ranks defined by Ray (1954) were collapsed to 3 categories: light, which includes very light and light infections; moderate, which includes light to moderate and moderate infections; and heavy, which includes moderate to heavy and heavy infections. H. nelsoni infections were rated as follows: localized $(\mathrm{LO})=$ any infection whereby plasmodia are localized in 1 small area in 1 tissue type, usually the epithelium of gills or gut; rare $(\mathrm{R})=$ systemic infections with less than 10 plasmodia in the entire section; light $(\mathrm{L})=$ systemic infections with less than 2 plasmodia per 400 field, but more than 10 plasmodia in the entire section; moderate $(M)=$ systemic infections with 2 to 5 plasmodia per 400 field; heavy $(\mathrm{H})$ $=$ more than 5 plasmodia per 40 field; sporulation $(\mathrm{S})=$ any infection where spores are present.

Sentinel and control oysters. Adult oysters (60 to $90 \mathrm{~mm}$ ) from the Damariscotta River, Maine, were collected and supplied monthly by the Pemaquid Oyster Company. Upon receipt, a sample $(n=25)$ of oysters was processed for disease diagnosis using both paraffin histology and standard Ray fluid thioglycollate medium assays (Ray 1954). The remaining oysters were immediately placed in temperature-controlled (equivalent to Maine water temperature at time of collection), $1 \mu \mathrm{m}$-filtered York River water, and gradually adjusted to ambient York River temperature conditions. Filtration removed Perkinsus marinus cells from ambient York River water, yielding specific pathogenfree water. During acclimation and holding periods, the oysters were maintained in $40 \mathrm{l}$ aquaria (20 to 25 oysters per aquarium) and fed daily $(0.1 \mathrm{~g}$ algal paste oyster ${ }^{-1}$ ).

Damariscotta River oysters $(\mathrm{n}=30)$ serving as sentinels were suspended from the VIMS pier at the York River site in retrievable trays on approximately the 1st and 15th of each month for a period of 14 to $16 \mathrm{~d}$ from 15 April 1994 through 15 December 1995. During each exposure period, a second group of Damariscotta oysters $(n=25)$, serving as a control, was maintained in the laboratory at ambient York River temperature and salinity conditions in $1 \mu \mathrm{m}$-filtered York River water. After the exposure period, 25 exposed and control oysters were maintained for a $30 \mathrm{~d}$ period in the laboratory in individual 11 aerated containers containing $1 \mu \mathrm{m}$-filtered York River water at 23 to $27^{\circ} \mathrm{C}$ and 18 to $22 \mathrm{ppt}$. It was anticipated that the 30 $\mathrm{d}$ holding period would provide time for subclinical early infections to intensify to detectable levels. During the laboratory holding period, the oysters were fed $0.1 \mathrm{~g}$ algal paste oyster ${ }^{-1}$ daily (Monday to Friday) and water was renewed every other day (Monday to Friday).

Perkinsus marinus body-burden determination. Following the holding period, P.marinus body-burdens in exposed and control oysters were determined using a modification of the body-burden technique described by Choi et al. (1989). Oysters were shucked and tissues were removed from shells. Whole oyster meats were finely minced using a razor blade, and were added to a tube containing $20 \mathrm{ml}$ of penicillin/streptomycin-fortified Ray fluid thioglycollate medium (RFTM) (Ray 1954). The tubes were incubated in the dark for $7 \mathrm{~d}$ at room temperature. After incubation, the samples were centrifuged at $1500 g$ for $10 \mathrm{~min}$ and the RFTM supernatant was removed. Pellets were resuspended in $30 \mathrm{ml}$ of $2 \mathrm{M} \mathrm{NaOH}$ and incubated at $60^{\circ} \mathrm{C}$ for 1 to $3 \mathrm{~h}$. The samples were pelleted by centrifugation at $1500 \mathrm{~g}$ for $10 \mathrm{~min}$, supernatants were removed, and pelleted cells were then washed 3 times in deionized water. After the final wash, the pellets were resuspended in 1 to $5 \mathrm{ml}$ of dilute Lugol's iodine solution. Subsamples were aspirated onto $47 \mathrm{~mm}$ diameter, $0.22 \mu \mathrm{m}$ filter paper, and stained $P$. marinus cells were counted using light microscopy at 50 magnification. When counts were greater than 200 , samples were serially diluted and triplicate $100 \mu \mathrm{l}$ aliquots were counted. Entire sample volumes were quantified when subsample counts contained fewer than 20 cells. Body burden counts are expressed as total parasite cells per oyster, and infection-acquisition rates are expressed as prevalence per deployment period.

Statistical analysis. Nonparametric Spearman rankcorrelation analyses of biweekly mean values of temperature, salinity, and immuno-labeled cell abundance, percent mortality per day, and prevalence (infection-acquisition rate of sentinel oysters) for corresponding biweekly exposure periods were conducted using Abacus Concepts, Statview software on a Macintosh computer. Percent mortality and prevalence values were arcsine-transformed, and immuno-labeled cell abundance values were log-transformed prior to analyses. Analyses were conducted on data split by year and on the entire data set. 


\section{RESULTS}

\section{Temperature and salinity}

Salinity and temperature profiles at the lower York River sampling site during the course of the study are shown in Fig. 1. Maximum temperatures occurred in July of each year and minimum temperatures were recorded in February 1995. Temperature was generally warmer in 1995 than in 1994. In 1995 , water temperature exceeded $20^{\circ} \mathrm{C}$ for a total of $159 \mathrm{~d}$ beginning about $17 \mathrm{May}$, and exceeded $25^{\circ} \mathrm{C}$ for $109 \mathrm{~d}$ beginning about 5 June. In contrast, in 1994, temperature exceeded $20^{\circ} \mathrm{C}$ for a period of $135 \mathrm{~d}$ beginning on 25 May, and exceeded $25^{\circ} \mathrm{C}$ for only $79 \mathrm{~d}$ beginning on 15 June. Relatively low salinity (10 to 15 ppt) was recorded from early April to mid-June 1994, but salinity was generally between 18 and 22 ppt through the remainder of the study.

\section{Enumeration of Perkinsus marinus in water samples}

Flow cytometric counts of immuno-labeled cells for individual water samples collected throughout the study are shown in Fig. 2. A distinct seasonal periodicity in cell abundance was observed; maximum abundances were observed in early August in both years, while relatively low abundances were observed during spring, fall and winter months.

In 1994, minor peaks in abundance counts of 500 to 1500 cells $\mathrm{l}^{-1}$ were observed in late April, mid-June, mid-July, and early September. Cell counts peaked in

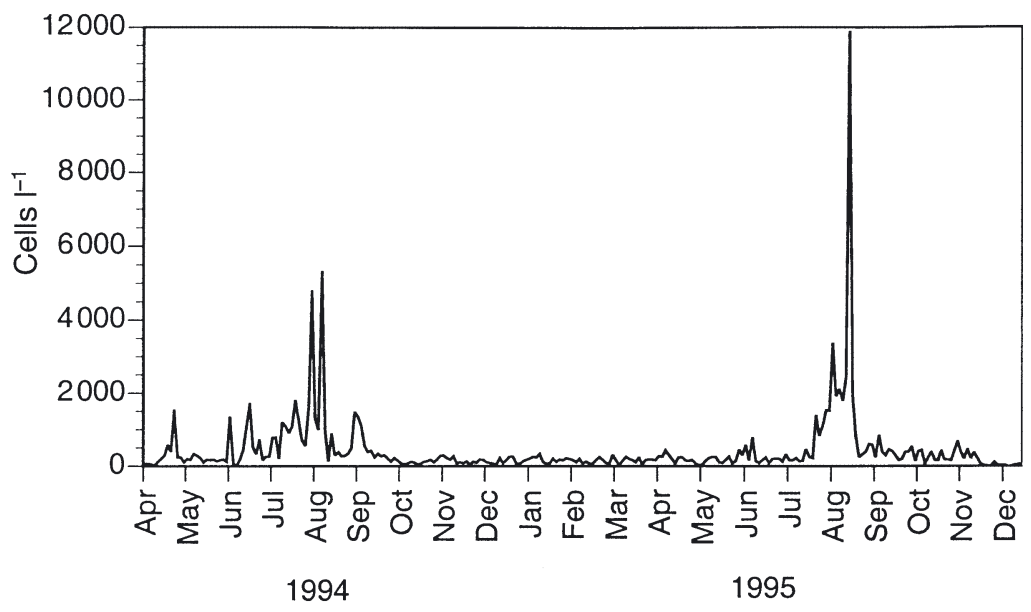

Fig. 2. Perkinsus marinus. Flow cytometric counts of antibody-labeled cells in York River water samples collected 3 times each wk during study period mid-summer with nearly all samples collected between 11 July and 10 August 1994 having counts exceeding 1000 cells $\mathrm{l}^{-1}$. The 2 highest counts, 4810 and 5330 cells $\mathbf{l}^{-1}$, were observed in samples collected on 1 August and 8 August, respectively. Water temperatures during the period that maximum immunolabeled cell abundances were observed exceeded $25^{\circ} \mathrm{C}$. From late September 1994 through late May 1995, little variability in abundance was observed, and cell counts remained below 200 cells $\mathrm{l}^{-1}$. Immunolabeled cells were detected in all 1994 water samples.

In 1995, spring and early summer peaks in immuno-labeled cells were not observed, and an early September increase in abundance was much less pronounced than in 1994. The mid-summer peak was much higher in magnitude, and both the onset and termination occurred slightly later than in 1994. Water temperature during this period ranged from 28 to $31^{\circ} \mathrm{C}$. The maximum abundance recorded in 1995, 11900 cells l $^{-1}$, occurred on 14 August. This count, which was nearly twice as high as the maximum count in 1994, coincided with an intense red tide. Only 1 other sample in 1995 had a count exceeding 2500 cells $~^{-1}$ and that was the 2 August sample, which had 3370 cells $1^{-1}$. Immuno-labeled cells were detected in all but two 1995 water samples.

\section{Oyster mortality}

Mortality of the infected native oysters did not differ significantly between replicate trays, so data were pooled for presen- 

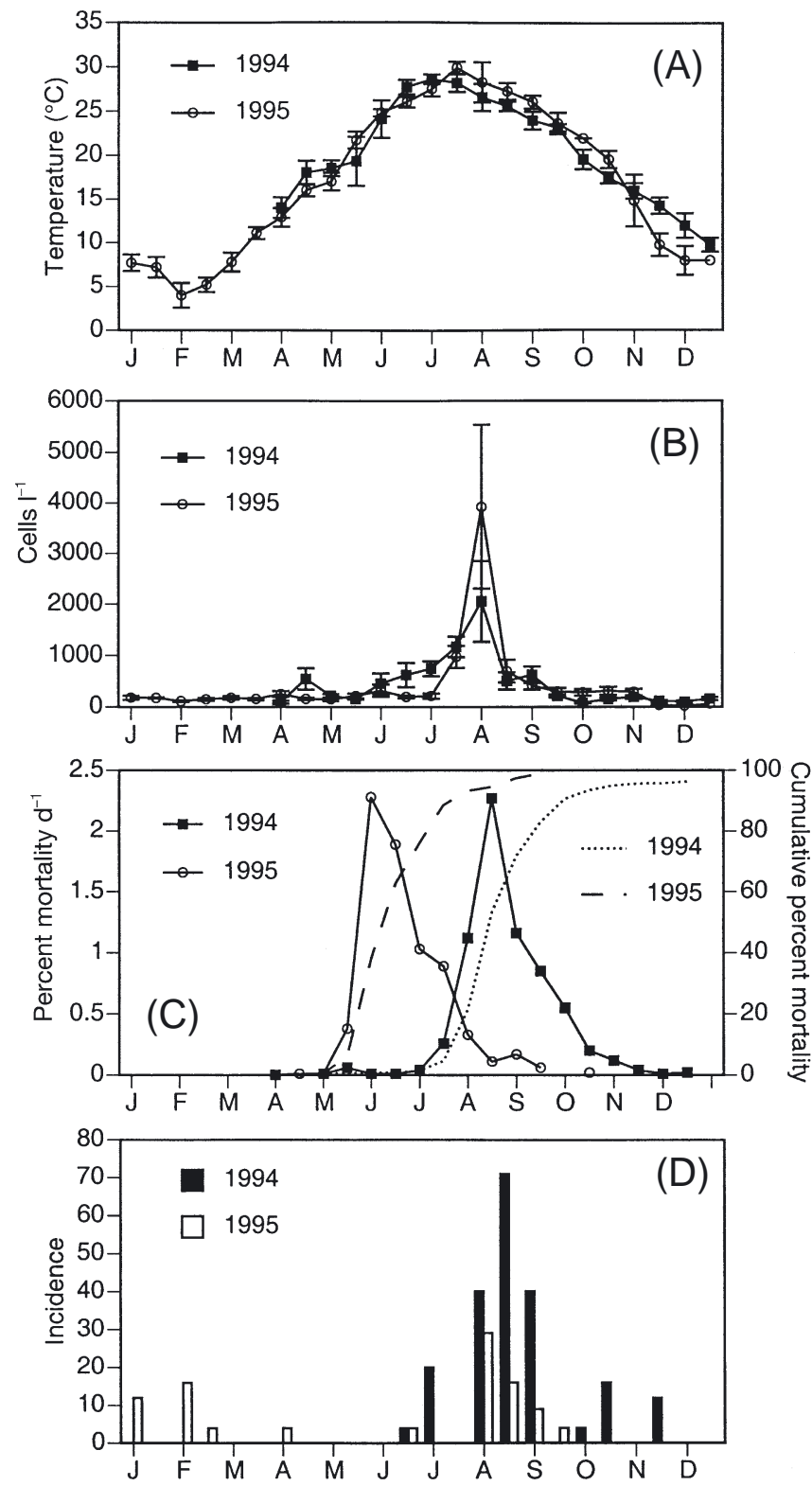

Fig. 3. (A) Biweekly mean temperature; (B) biweekly mean count of Perkinsus marinus antibody-labeled cells; (C) biweekly interval mortality (continuous lines) and cumulative mortality rates (dotted and dashed lines) of captive host oysters; (D) $P$. marinus infection-acquisition in biweeklydeployed sentinel oysters. Data for 1994 and 1995 are compared

tation and analysis. In both 1994 and 1995, more than $95 \%$ of the infected native oysters died between April and November (Fig. 3C). Although final cumulative mortality was similar for the 2 years, the timing of onset and maximum mortality rates differed significantly between years. In 1994, most of the mortality occurred between 7 July and 26 October. During this time a sin- gle major peak in biweekly mortality rate was observed. Rate of mortality increased rapidly from $0.26 \% \mathrm{~d}^{-1}$ during the interval 7 to 19 July to $1.12 \% \mathrm{~d}^{-1}$ for the interval 19 July to 3 August, and was highest during the interval 3 to 17 August $\left(2.27 \% \mathrm{~d}^{-1}\right.$ ) (Fig. 3C). Dead oysters retrieved on 3 August and 17 August had high prevalences of both Perkinsus marinus and Haplosporidium nelsoni (Table 1, Fig. 4). Of the 50 dead oysters retrieved on these 2 dates, 30 had heavy infections of $P$. marinus and 19 had heavy infections of $H$. nelsoni. Overall, of the 83 dead oysters examined between 19 July and 13 October, 72 had moderate or heavy $P$. marinus infections and 43 had moderate or heavy $H$. nelsoni infections. Maximum mortality rates were observed during, and immediately following, maximum summer temperatures (Fig. 3A,C). The increase in mortality rate during July and early August coincided with maximum abundance of immunolabeled cells in the water column (Fig. 3B,C); however, relatively high mortality rates in late August and early September (Fig. 3C) were associated with relatively low abundances of immuno-labeled cells (Fig. 3B).

In contrast to the pattern of mortality observed in 1994, in 1995 infected native oysters began dying much earlier in the summer as a result of an early Haplosporidium nelsoni epizootic: $63 \%$ of the oysters died between 31 May and 27 June (Fig. 3C). H. nelsoni prevalence in dead infected native oysters was $100 \%$, with a high proportion of heavy infections, while Perkinsus marinus prevalence was only 17 to $25 \%$, with no heavy infections (Table 1, Fig. 4). Oyster mortality continued to occur at a relatively high rate, $>0.89 \% \mathrm{~d}^{-1}$, to the end of July, and cumulative mortality increased to $89 \%$. Mortality decreased to $0.33 \% \mathrm{~d}^{-1}$ in early August and ranged from 0.11 to $0.17 \% \mathrm{~d}^{-1}$ in September. Fewer than $3 \%$ of the oysters in the infected native population remained alive at this time.

Biweekly mortality rate correlated significantly with biweekly mean water temperature in both years of the study (Table 2). In 1994, a significant correlation was found between biweekly mortality rate and biweekly mean abundance of immuno-labeled cells (Table 2). The 2 factors did not correlate significantly in 1995.

\section{Infection acquisition in sentinel oysters}

Between 7 April 1994 and 15 November 1995, 38 biweekly deployments of sentinel oysters were made. Oysters in 17 of the 38 groups exhibited Perkinsus marinus infections following a 14 or $15 \mathrm{~d}$ deployment and $30 \mathrm{~d}$ intensification period (Table 3, Fig. 3D). In both 1994 and 1995, maximum rates of $P$. marinus infection acquisition by the sentinel oysters occurred 
Table 1. Prevalence and intensity of Perkinsus marinus and Haplosporidium nelsoni in dead oysters retrieved from $P$. marinus-infected native oyster population in 1994 and in 1995; intensity of parasite infections ranked as light (L), moderate (M) or heavy $(\mathrm{H}) ; \mathrm{N} / \mathrm{N}$ : no. of oysters infected/no. examined; na: not analyzed

\begin{tabular}{|c|c|c|c|c|c|c|}
\hline \multirow{2}{*}{$\begin{array}{l}\text { Collection } \\
\text { date }\end{array}$} & \multicolumn{3}{|c|}{ P. marinus } & \multicolumn{3}{|c|}{ H. nelsoni } \\
\hline & N/N & Prev. \% & $\begin{array}{l}\text { Intensity } \\
\text { L-M-H }\end{array}$ & $\mathrm{N} / \mathrm{N}$ & Prev. \% & $\begin{array}{c}\text { Intensity } \\
\text { L-M-H }\end{array}$ \\
\hline \multicolumn{7}{|l|}{1994} \\
\hline Jul 19 & $4 / 4$ & 100 & $1-1-2$ & na & & \\
\hline Aug 3 & $24 / 25$ & 96 & $5-6-13$ & $22 / 24$ & 92 & $11-4-7$ \\
\hline Aug 17 & $25 / 25$ & 100 & $3-5-17$ & $17 / 25$ & 68 & $4-1-12$ \\
\hline Sep 2 & $5 / 5$ & 100 & $1-0-4$ & $7 / 7$ & 100 & $0-0-7$ \\
\hline Sep 15 & $10 / 10$ & 100 & $0-3-7$ & $9 / 10$ & 90 & $3-1-5$ \\
\hline Sep 29 & $10 / 10$ & 100 & $0-0-10$ & $10 / 10$ & 100 & $5-1-4$ \\
\hline Oct 13 & $4 / 4$ & 100 & $0-1-3$ & $2 / 4$ & 50 & $1-0-1$ \\
\hline \multicolumn{7}{|l|}{1995} \\
\hline May 31 & na & & & $10 / 10$ & 100 & $3-1-6$ \\
\hline Jun 14 & $3 / 12$ & 25 & $1-2-0$ & $12 / 12$ & 100 & $3-0-9$ \\
\hline Jun 27 & $1 / 6$ & 17 & $0-1-0$ & $6 / 6$ & 100 & $1-3-2$ \\
\hline Jul 10 & $3 / 5$ & 60 & $1-1-1$ & $4 / 5$ & 80 & $2-1-1$ \\
\hline Aug 9 & $1 / 1$ & 100 & $0-0-1$ & $0 / 1$ & 0 & $0-0-0$ \\
\hline
\end{tabular}

In addition to the distinct peaks in Perkinsus marinus infection incidences, which occurred during August and September, the parasite was sporadically detected at lower incidences in sentinel oysters at other times of the year: June, July, October, November 1994 and January, February and April 1995 (Fig. 3D). The highest incidence observed in these groups was $20 \%$ and in most cases the whole-oyster parasite burdens were less than 5 cells oyster $^{-1}$ (Table 3).

\section{Infection in control oysters}

Perkinsus marinus was detected in only 1 of the monthly subsamples of Damariscotta oysters examined upon arrival at VIMS. The subsample, which was collected on 2 August 1995, had a during August and September. However, incidences of $P$. marinus infections in the sentinel oysters varied significantly between years. Maximum 15 d P. marinus infection incidences were $71 \%$ in 1994 and $29 \%$ in 1995 (Table 3, Fig. 3D). In 1994, maximum infection acquisition in sentinel oysters coincided with maximum hostmortality rates and biweekly mean water temperatures of 24 to $27^{\circ} \mathrm{C}$ (Fig. 3A,C,D). During 1995, maximum P. marinus transmission coincided with relatively low hostmortality rates and biweekly water temperature means that ranged from 26 to $28^{\circ} \mathrm{C}$. In both years, peaks in $P$. marinus infection acquisition occurred during periods of elevated abundance of immunolabeled cells in the water column. Mean abundance of immuno-labeled cells for the exposure periods having the highest transmission rates ranged from 416 to 3920 cells $\mathrm{l}^{-1}$ (Fig. 3B). Although the high transmission rates observed coincided with elevated cell counts, the correlation between biweekly averaged cell count and infection incidence was not significant. In 1994, maximum transmission did not overlap with the highest water-column cell abundance, and there were other exposure periods in which cell abundance was high but infections were not acquired by the sentinel oysters.
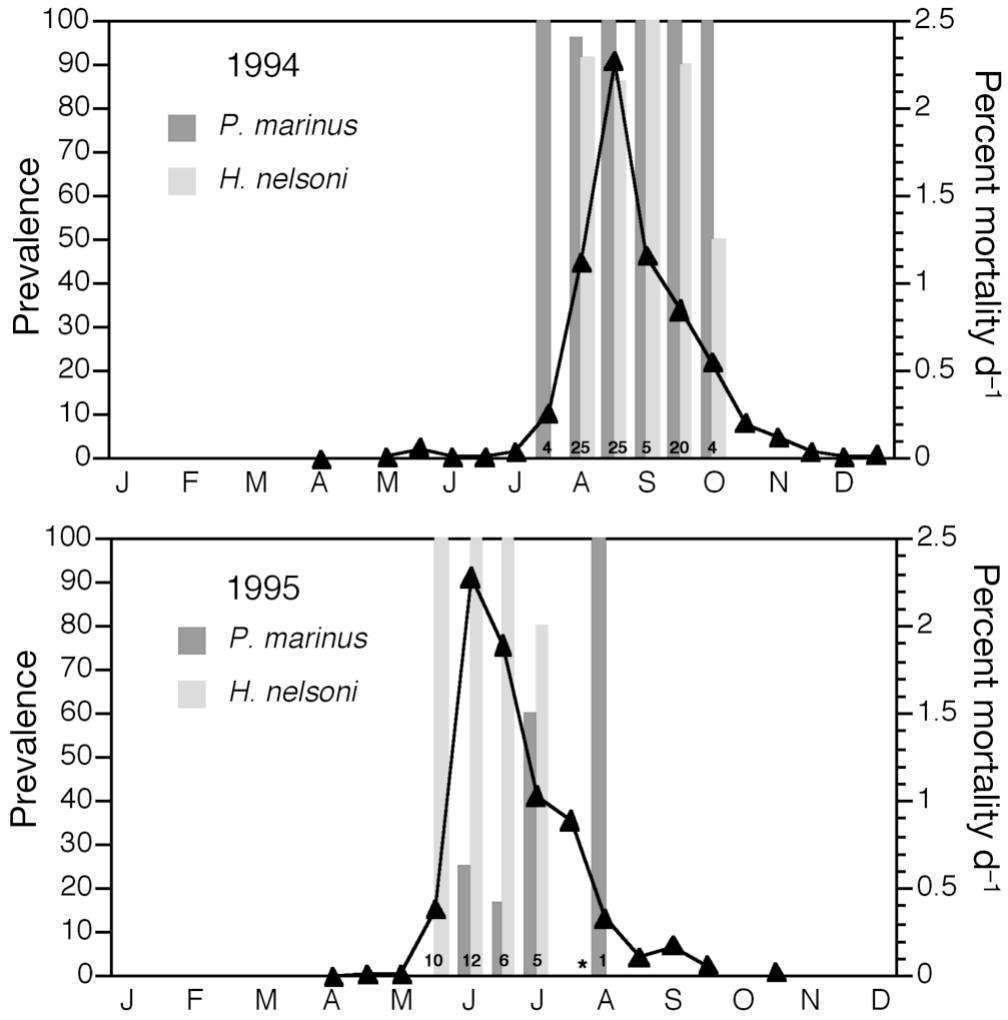

Fig. 4. Crassostrea virginica. Biweekly mortality rate (lines) in captive hostoyster populations and prevalence of Perkinsus marinus and Haplosporidium nelsoni in retrieved dead oysters (bars). Relationship shown for captive oyster populations monitored in 1994 and 1995. Absence of bars = no dead oysters retrieved on that date; ${ }^{*}=$ no infections in sample; numbers at bottom of bars $=$ sample size for that date 
Table 2. Correlation of mean immuno-labeled cell counts, mean temperature, biweekly mortality rate of source oysters, and Perkinsus marinus incidence in exposed sentinel oysters. All data are biweekly. Significant correlations $(p<0.05)$ indicated by asterisks. CC: correlation coefficient (Spearman's rho)

\begin{tabular}{|lcc|}
\hline Parameters & CC & p-value \\
\hline 1994 + 1995 & & \\
Temperature + cell count & 0.783 & $<0.0001^{*}$ \\
Temperature + mortality & 0.780 & $<0.0001^{*}$ \\
Temperature + incidence & 0.296 & 0.0718 \\
Mortality + cell count & 0.550 & $0.0011^{*}$ \\
Mortality + incidence & 0.272 & 0.1082 \\
Cell count + incidence & 0.304 & 0.0646 \\
1994 & & \\
Temperature + cell count & 0.777 & $0.0014^{*}$ \\
Temperature + mortality & 0.596 & $0.0170^{*}$ \\
Temperature + incidence & 0.449 & 0.0728 \\
Mortality + cell count & 0.520 & $0.0377^{*}$ \\
Mortality + incidence & 0.604 & $0.0158^{*}$ \\
Cell count + incidence & 0.346 & 0.1669 \\
1995 & & \\
Temperature + cell count & 0.759 & $0.0003^{*}$ \\
Temperature + mortality & 0.851 & $0.0003^{*}$ \\
Temperature + incidence & 0.141 & 0.5295 \\
Mortality + cell count & 0.648 & $0.0060^{*}$ \\
Mortality + incidence & -0.038 & 0.8729 \\
Cell count + incidence & 0.254 & 0.2556 \\
\hline
\end{tabular}

prevalence of $8 \%$ (2 of 25). Both of the infected oysters had light-intensity infections. $P$. marinus infections were detected in 8 of the 38 control groups after the 30 d laboratory intensification period (Table 3). Infections occurred in control oysters both at times when deployed oysters did and did not exhibit $P$. marinus infections. $P$. marinus prevalence in the control groups did not exceed $8 \%$. Body-burden analysis of $P$. marinus-infected control oysters revealed only 1 to 2 parasite cells in all but 1 case, which had 120 parasite cells. With the exception of 2 oysters from the 8 June 1994 import sample, in which $H$. nelsoni was found, no other parasites or abnormalities were observed in the oysters examined upon arrival from Maine.

\section{DISCUSSION}

This study is the first to systematically examine the seasonality of Perkinsus marinus infection-acquisition in oysters in relation to the abundance of $P$. marinus cells in the water column, local oyster mortality, temperature, and salinity. The results demonstrate that $P$. marinus transmission is highest in mid-summer during periods of high host-mortality, and support the hypothesis that infective stages of the parasite originate from dying oysters.
In both years of the study, infected native oysters, which harbored overwintering Perkinsus marinus infections, were monitored to estimate mortality rates in local oyster populations and to determine the relationship of host mortality to environmental abundance of immuno-labeled cells and infection-acquisition rate. Interestingly, striking differences in the timing of oyster mortalities were observed between years. In 1994, little mortality occurred prior to 19 July; however, over the course of the following 6 wk nearly $70 \%$ of the oysters in the infected native oyster population perished. Mortalities were attributed to co-infections of $P$. marinus and Haplosporidium nelsoni. The timing of mortality corresponded with that reported in previous studies in the lower Chesapeake Bay (Andrews 1965, 1967, 1988, Andrews \& Wood 1967). Oyster mortality occurred during and immediately after maximum summer temperatures, and the correlation between oyster mortality and temperature was strong. It is likely that high summer temperatures enhance $P$. marinus multiplication and pathogenicity within host oysters.

In 1995, the onset of oyster mortality occurred much earlier than in 1994, with more than $75 \%$ of the oysters dying by mid-July. We attribute these atypically high early-summer oyster deaths to Haplosporidium nelsoni because of the high prevalence and intensity of this parasite at the time. Although Perkinsus marinus was present in the oyster population, parasite burdens were well below lethal levels. While concurrent lowlevel $P$. marinus infections may have acted synergistically with $H$. nelsoni to cause oyster deaths, the oysters would not have died had $H$. nelsoni been absent. $P$. marinus did not contribute significantly to oyster deaths until overwintering infections began to intensify in mid-July, but by then a large proportion of the population (75\%) had already died. Cumulative mortality continued to increase through the late summer and fall, and reached $95 \%$ by the end of October. As in 1994, biweekly mortality rates significantly correlated with water temperature in 1995; however, the strength of the association was not as strong as in 1994.

Immuno-labeled cells were present in York River water samples throughout the year. Significant seasonal variation in cell abundance was observed, with annual maxima in mid-summer and relatively low abundances in fall, winter and spring. Environmental abundances of immuno-labeled cells were significantly correlated with water temperature. The spring rise in abundance corresponded to an increase in water temperature to about $18^{\circ} \mathrm{C}$. Springtime peaks in abundance were observed in late April 1994 and to a lesser extent in early April 1995; however, abundance declined again in May of both years, and elevated levels were not again observed until June. In 1994 there were more counts that exceeded 1000 cells $~^{-1}$ than in 
Table 3. Crassostrea virginica. Incidence of Perkinsus marinus and parasite burden-intensity in York River-exposed sentinel oysters and in laboratorymaintained control oysters. Sentinel oysters were exposed to $P$. marinus naturally, and control oysters were held under controlled laboratory conditions for 14 to $15 \mathrm{~d}$ periods. Body burdens were determined after $30 \mathrm{~d}$ laboratory-holding period that allowed time for subclinical infections to intensify. Ranges, means $( \pm \mathrm{SD})$ of whole oyster parasite burdens (total parasite cells oyster ${ }^{-1}$ ) for infected individuals are shown

\begin{tabular}{|c|c|c|c|c|c|c|}
\hline \multirow{2}{*}{$\begin{array}{l}\text { Deployment } \\
\text { period }\end{array}$} & \multirow{2}{*}{$\begin{array}{l}\text { Incidence } \\
(\%)\end{array}$} & \multicolumn{2}{|c|}{ Sentinel oysters } & \multirow{2}{*}{$\begin{array}{c}\text { Incidence } \\
(\%)\end{array}$} & \multicolumn{2}{|c|}{ Control oysters } \\
\hline & & $\begin{array}{c}\text { Parasite } \\
\text { burden } \\
\text { Range }\end{array}$ & $\begin{array}{l}\text { Mean } \\
( \pm \text { SD })\end{array}$ & & $\begin{array}{c}\text { Parasite } \\
\text { burden } \\
\text { Range }\end{array}$ & $\begin{array}{l}\text { Mean } \\
( \pm \mathrm{SD})\end{array}$ \\
\hline \multicolumn{7}{|l|}{1994} \\
\hline Apr $15-30$ & 0 & & & 0 & & \\
\hline May 1-15 & 0 & & & 8 & $1-3$ & $2(1.4)$ \\
\hline May 16-31 & 0 & & & 0 & & \\
\hline Jun 1-15 & 0 & & & 0 & & \\
\hline Jun $16-30$ & 4 & 85 & & 0 & & \\
\hline Jul 1-15 & 20 & $1-2010$ & $406.8(896.2)$ & 0 & & \\
\hline Jul $15-30$ & 0 & & & 0 & & \\
\hline Aug 1-16 & 40 & $1-5025$ & $528.2(1581.0)$ & 8 & $1-4$ & $2.5(2.1)$ \\
\hline Aug 17-31 & 71 & $1-1505$ & $104.1(361.7)$ & 4 & 120 & \\
\hline Sep 1-15 & 40 & $1-187$ & $21.6(41.0)$ & 4 & 1 & \\
\hline Sep 16-30 & 0 & & & 0 & & \\
\hline Oct 1-15 & 4 & 1 & & 0 & & \\
\hline Oct $16-31$ & 16 & $1-2$ & $1.5(0.58)$ & 0 & & \\
\hline Nov 1-15 & 0 & & & 0 & & \\
\hline Nov $16-30$ & 12 & $1-2$ & $1.6(0.58)$ & 0 & & \\
\hline Dec 1-15 & 0 & & & 0 & & \\
\hline Dec $16-J a n ~ 2$ & 0 & & & 0 & & \\
\hline 1995 & & & & 0 & & \\
\hline Jan 2-16 & 0 & & & 0 & & \\
\hline Jan $17-F e b 1$ & 0 & & & 0 & & \\
\hline Feb 2-16 & 16 & $2-28$ & $9.25(12.6)$ & 0 & & \\
\hline Feb 17-Mar1 & 4 & & & 0 & & \\
\hline Mar2-16 & 0 & & & 4 & 1 & \\
\hline Mar 17-31 & 0 & & & 0 & & \\
\hline Apr 1-17 & 4 & 4 & & 0 & & \\
\hline Apr 18-May 1 & 10 & & & 5 & 1 & \\
\hline May 2-15 & 0 & & & 0 & & \\
\hline May 16-31 & 0 & & & 0 & & \\
\hline Jun 1-14 & 0 & & & 0 & & \\
\hline Jun 15-30 & 4 & 4 & & 0 & & \\
\hline Jul 1-15 & 0 & & & 0 & & \\
\hline Jul 16-30 & 0 & & & 0 & & \\
\hline Aug 1-15 & 29 & $2-87$ & $28.85(31.5)$ & 0 & & \\
\hline Aug 16-31 & 16 & $1-215$ & 73.5 (98.5) & 4 & 1 & \\
\hline Sep 1-15 & 9 & $1-2$ & $1.5(0.71)$ & 0 & & \\
\hline Sep 16-30 & 4 & 1 & & 0 & & \\
\hline Oct $1-15$ & 0 & & & 4 & 1 & \\
\hline Oct $16-31$ & 0 & & & 0 & & \\
\hline Nov 1-15 & 0 & & & 0 & & \\
\hline
\end{tabular}

1995; however, there was somewhat more variability in 1994 with periodic pulses of cell numbers $>1000$ cells $\mathrm{l}^{-1}$, followed by periods of relatively low, $<300$ cells $1^{-1}$, abundance. The maximum count, 11900 cells $\mathrm{l}^{-1}$, which was observed on 14 August 1994, was nearly double the maximum observed in 1995. The late-summer and fall of 1995 was warmer than 1994, and abundances of immuno-labeled cells during this period were generally higher in 1995 than 1994. It was not until mid-November that abundance consistently re-

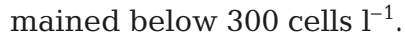

A recent study (e.g. Bushek et al. 2002a) has demonstrated that the polyclonal Perkinsus marinus anti-body crossreacts with several free-living, phototrophic and parasitic dinoflagellate species. The relatively large sizes, textured surfaces, and orange-red chlorophyll autoflourescence typical of phototrophic dinoflagellates, should together or individually have excluded them from enumeration based, respectively, on FALS, (90)LS, and REDFL criteria, even if they were immunolabeled by cross-reacting anti- $P$. marinus antibodies. The specific flow cytometric parameters utilized in the present study should have excluded enumeration of non-specific targets; however, independent verification was limited. Because of the broad labeling of multiple Perkinsus species by our antibody, it is possible that other Perkinsus species may have been sampled and enumerated during this study. Species-specific diagnostic tools are necessary to distinguish $P$. marinus cells from other Perkinsus species in the water column.

The biweekly abundance of immuno-labeled cells in the water column significantly correlated with the mortality rate of infected native oysters. The association of host mortality and immuno-labeled cell abundance supports the hypothesis that the parasite is disseminated via the death and decomposition of infected hosts. However, the presence of periodic minor peaks in cell abundances during periods with relatively low or negligible host mortality suggests that alternate sources of Perkinsus marinus cells may also be important. Alternative hypotheses suggest that cell abundances may be associated with host spawning and/or excretory activities, alternate host or vector activities, heterotrophic parasite proliferation, or periodic resuspension of parasite cells present in sediments. Scanlon (1997) and Bushek et al. (2002b) demonstrated that living oysters with moderate-to-heavy $P$. marinus infections commonly shed hundreds to thousands of 
viable $P$. marinus cells in their feces each day. Their findings support the hypothesis that environmental cell abundances may be associated with oyster excretory activities. The release of high numbers of pathogen cells from living oysters may obviate the need for oyster hosts to die in order for pathogen dissemination and transmission to occur. As suggested by Bushek et al. (2002b), this discharge may be particularly important prior to the intensification of infections to lethal levels. However, the abundance of parasite cells released in feces has been shown to be relatively small compared to that released from dead oysters with lethal $P$. marinus body burdens (Bushek et al. 2002b). The results of the present study support the finding of Bushek et al. (2002b) and suggest that the primary mode of $P$. marinus transmission is the release of infective stages from dead hosts.

The pattern of infection acquisition in sentinel oysters exposed to Perkinsus marinus endemic waters during this study is consistent with the longstanding hypothesis that infective cells arise from death and decomposition of infected hosts. The highest rates of infection acquisition by sentinel oysters were observed during August and September, a period during which host oysters were dying as a result of $P$. marinus infection. However, the association between oyster mortality and infection acquisition is not straightforward. Statistical analyses revealed a significant correlation between host mortality and P. marinus infection-acquisition rates in 1994 but not in 1995. In 1995, infection incidences were relatively low and $P$. marinus infection acquisition occurred outside the period of epizootic host mortalities. The mismatch of $P$. marinus infection-acquisition rate and host mortality partially reflects the fact that a high proportion of the infected native oyster population was killed early in the summer by a second pathogen, H. nelsoni. This finding suggests that Haplosporidium nelsoni can have a significant indirect influence on the transmission dynamics of $P$. marinus. Severe early summer epizootics of $H$. nelsoni may result in the death of oysters that harbor a reservoir of $P$. marinus cells, which in a normal year would intensify to lethal levels later in the summer. Perkinsus marinus infections that have time to intensify to lethal levels would result in the dissemination of a significantly greater abundance of $P$. marinus cells than in those hosts killed early by $H$. nelsoni. By killing hosts early in the summer, $H$. nelsoni limits the overall abundance of disseminated $P$. marinus cells.

On occasion, Perkinsus marinus was detected in laboratory control oysters, but in all instances prevalences and infection intensities in the controls were low, and in all but 1 instance infections were observed only after being allowed to intensify for more than $30 \mathrm{~d}$. Since the control oysters were carefully maintained in $1.0 \mu \mathrm{m}$ filtered York River water, it is unlikely that infections were acquired during laboratory holding. More likely, the infections originated in Maine. The presence of infections in several control groups somewhat confounds interpretation of our results, particularly with respect to the low infection incidences that were observed throughout the year. Low-prevalence and low-intensity infections that were observed in exposed oysters, but within the range of control oyster infections, may also have originated in Maine and been present in the oysters at the beginning of the exposure period.

A low percentage of the sentinel oysters acquired infections during the months of October to February, at temperatures of 15 to $4^{\circ} \mathrm{C}$. Although infections were not necessarily observed in control oysters during exactly the same periods, infections were generally very low and within the range of infections that were occasionally observed in control oysters. It is difficult to say whether these 'off season' infections were in fact acquired during the exposure period or were present upon arrival from Maine, as observed prevalences were within the range of error associated with infection-detection methods. In previous studies, sentinel oysters in Chesapeake Bay Perkinsus marinus-endemic waters did not acquire infections after about 1 November (Andrews 1965). The absence of new infections during the late fall and winter months is thought to be associated with temperature-induced depressions of host-oyster mortality that would limit the abundance of infective cells, and to more efficient host-defense activities (Andrews 1988). More recently, in laboratory experiments where $P$. marinus meronts were injected into the mantle cavity of oysters held at various temperatures, infections were established at temperatures as low as $10^{\circ} \mathrm{C}$ (Chu \& LaPeyre 1993). These laboratory results support the observations reported here, and suggest that parasite transmission may not be limited to the summer months. Relatively high counts of immunolabeled cells in the water column were recorded during the period of peak seasonal infection pressure. The correspondence of immuno-labeled cells in the environment with annual peaks in $P$. marinus infection-incidence confirms that the infective stages of $P$. marinus were present in the environment during that time. However, the maximum immuno-labeled cell counts did not always coincide with high rates of infection acquisition. For instance, in 1994, the abundance of immuno-labeled cells in late July were nearly as high as in early August, but no infections were acquired by sentinel oysters deployed during 
the former month. There are several possible explantions for these mismatches in the period of peak annual immuno-labeled cell abundance and peak infection incidence: (1) there could be an undocumented high daily variability in environmental parasite cell abundances that was not adequately detected with our sampling schedule, (2) the enumerated cells may not be equally infective, or only some variable fraction of enumerated cells may be infective, (3) a lag time is required for cells in the environment to transform to an alternate not enumerated 'stage', prior to infection, (4) natural infection processes are non dose dependent, (5) environmental factors other than those measured influence parasite transmission, and (6) the enumerated cells were not all $P$. marinus. Further research is required to determine which of these factors are relevant.

The periodic deployment of sentinel oysters has enabled the assessment of relative infection pressures throughout the year. The absence of infections during a specific period does not necessarily indicate that infections cannot be acquired during that period. Duration of exposure may be an important factor, and longer exposure periods would most probably result in higher rates of infection acquisition.

Acknowledgements. We greatly appreciate the expert assistance of several individuals. Anna Schotthoefer, VIMS, collected and processed all water samples, performed Perkinsus marinus body-burden diagnostic assays, and maintained and assessed mortality of captive oyster populations. Tong Li, University of Maryland, assisted with the development of flow cytometric protocols and was responsible for flow cytometric enumeration of $P$. marinus cells in environmental water samples. Juanita Walker, VIMS, was responsible for paraffin histology and provided assistance with processing oysters for body-burden analyses. Caroline O'Farrell, Sandra Blake, and Brenda Flores, VIMS, provided assistance with processing oysters for body-burden analyses. Kenneth Walker, VIMS, collected James River oysters. Funding for this project was provided by NOAA Oyster Disease Research Program (Grant Number NA47FLO159). VIMS contribution number 2554.

\section{LITERATURE CITED}

Andrews JD (1965) Infection experiments in nature with Dermocystidium marinum in Chesapeake Bay. Chesapeake Sci 6:60-67

Andrews JD (1967) Interaction of two diseases of oysters in natural waters. Proc Natl Shellfish Assoc 57:38-49

Andrews JD (1988) Epizootiology of the disease caused by the oyster pathogen Perkinsus marinus and its effect on the oyster industry. Am Fish Soc Spec Publ 18:47-63

Andrews JD, Hewatt WG (1957) Oyster mortality studies in Virginia. II. The fungus disease caused by Dermocystidium marinum in oysters of Chesapeake Bay. Ecol Monogr $27: 1-26$
Andrews JD, Wood JL (1967) Oyster mortality studies in Virginia. VI. History and distribution of Minchinia nelsoni, a pathogen of oysters in Virginia. Chesapeake Sci 8:1-13

Ashton-Alcox KA, Allam B, Ford SE (2000) Application of flow cytometry to bivalve pathology. In: Fingerman M, Nagabhushanam R (eds) Recent advances in marine biotechnology, Vol 5. Immunology and pathology. Science Publishers, Enfield, NH, p 85-124

Burreson EM, Ragone Calvo LM (1996) Epizootiology of Perkinsus marinus disease of oysters in Chesapeake Bay, with emphasis on data since 1985. J Shellfish Res 15:17-34

Bushek D, Ford SE, Allen SK Jr (1994) Evaluation of methods using Ray's fluid thioglycollate medium for diagnosis of Perkinsus marinus infection in the eastern oyster, Crassostrea virginica. Annu Rev Fish Dis 4:201-217

Bushek D, Dungan CF, Lewitus AJ (2002a) Seriological affinities of the oyster pathogen Perkinsus marinus (Apicomplexa) with some dinoflagellates (Dinophyceae). J Eukaryot Microbiol 49:11-16

Bushek D, Ford SE, Chintala MM (2002b) Comparison of in vitro-cultured and wild-type Perkinsus marinus. III. Fecal elimination and its role in transmission. Dis Aquat Org 51: $217-225$

Choi KS, Wilson EA, Lewis DH, Powell EN, Ray SM (1989) The energetic cost of Perkinsus marinus parasitism in oysters: quantification of the thioglycollate method. J Shellfish Res 8:125-131

Chu FE, LaPeyre JF (1993) Perkinsus marinus susceptibility and defense-related activities in eastern oysters Crassostrea virginica: temperature effects. Dis Aquat Org 16:223-234

Dungan CF, Hamilton RM (1995) Use of a tetrazolium-based cell proliferation assay to measure effects of in vitro conditions on Perkinsus marinus (Apicomplexa) proliferation. J Eukaryot Microbiol 42:379-388

Dungan CF, Roberson BS (1993) Binding specificities of mono- and polyclonal antibodies to the protozoan oyster pathogen Perkinsus marinus. Dis Aquat Org 15:9-22

Mackin JG (1962) Oyster disease caused by Dermocystidium marinum and other microorganisms in Louisiana. Pub Inst Mar Sci Univ Tex 7:132-229

Perkins FO (1966) The structure of Perkinsus marinus (Mackin, Owen, and Collier, 1950) Levine, 1978, with comments on taxonomy and phylogeny. J Shellfish Res 15:67-88

Perkins FO (1988) Structure of protistan parasites found in bivalve molluscs. Am Fish Soc Spec Pub 18:93-111

Ragone Calvo LM, Burreson EM (1993) Characterization of overwintering infections of Perkinsus marinus (Apicomplexa) in Chesapeake Bay oysters. J Shellfish Res 13: $123-130$

Ragone Calvo LM, Burreson EM (1999) Status of the major oyster diseases in Virginia, 1998. Virginia Institute of Marine Science, 99-3, Gloucester Point, VA

Ray SM (1954) Biological studies of Dermocystidium marinum, a fungus parasite of oysters. Rice Institute Pamphlet Special. The Rice Institute, Houston, TX

Roberson BS, Li T, Dungan CF (1993) Flow cytometric enumeration and isolation of immunofluorescent Perkinsus marinus cells from estuarine waters. J Shellfish Res 12 : 138

Roberson BS, Li T, Dungan CF, Burreson EM (1995) Flow cytometric enumeration of Perkinsus marinus cells in Chesapeake Bay waters. Completion Report NA47FL0159. NOAA Chesapeake Bay Office, Annapolis, MD

Scanlon CH (1997) The potential for transmission of Perkinsus marinus by fecal matter from the eastern oyster, Crassostrea virginica. Master's thesis, Virginia Institute of 
Marine Science, Gloucester Point, VA

Sunila I, Hamilton RM, Dungan CF (2001) Ultrastructural characteristics of the in vitro cell cycle of the protozoan pathogen of oysters, Perkinsus marinus. J Eukaryot Microbiol 48:348-361

Editorial responsibility: Albert Sparks,

Seattle, Washington, USA
Volety AK, Chu FLE (1994) Comparison of infectivity and pathogenicity of meront (trophozoite) and prezoosporangia stages of the oyster pathogen Perkinsus marinus in eastern oysters, Crassostrea virginica (Gmelin, 1791). J Shellfish Res 13:521-527

Submitted: November 17, 2001; Accepted: May 5, 2003 Proofs received from author(s): July 23, 2003 